\title{
Canadians and their Pasts
}

Michelle A. Hamilton, Director of Public History, The University Western Ontario

\section{http://www.canadiansandtheirpasts.ca/}

Begun in 2006, this Social Sciences and Humanities Research Council (SSHRC) supported project explores how Canadians engage with their own past and the history of Canada in their everyday life. The genesis of this project stemmed from the investigators' shared sense that the public's interest and stake in the past was growing, an issue they felt needed examination in order to evaluate the recent debates about the importance of an overarching national narrative. Principal Investigator Jocelyn Létourneau (Laval) and co-investigators Margaret Conrad (University of New Brunswick), Gerry Friesen (Manitoba), Del Muise (Carleton), David Northrup (York), and Kadriye Ercikan and Peter Seixas (University of British Columbia) were also inspired by previous projects in other countries which found that public and academic understandings of the past vary greatly. With numerous other individual and institutional partners, the project team aimed to assess systematically Canadians' historical consciousness. ${ }^{1}$

Modelled after previous projects carried out in the United States, Australia and Europe, the Canadian team planned to contact several thousand Canadians over the telephone. ${ }^{2}$ Through 2007 and 2008, Jolicoeur and Associés of Montreal and the Institute for Social Research at York University implemented these extensive surveys consisting of approximately seventy questions. Each of five regions - British Columbia, the prairies, Ontario, Quebec and Atlantic Canada - were allocated an equal 400 surveys. Parks Canada ordered another 1000 urban interviews in Toronto, Calgary, Montreal, Edmonton and Vancouver. In order to explore potential regional and ethnic differences in the understanding and use of the past, an extra 100 surveys were conducted each with New Brunswick Acadians, First Nations in the Saskatoon area, and with recent immigrants in the greater Toronto region of Peel. ${ }^{3}$ In addition to the over 3000 Canadians who answered the surveys via telephone, several institutional partners conducted more targeted focus groups which further broadened the regional, ethnic and occupational diversity of the respondents.

As Létourneau writes, one should not mistake ignorance of the past for indifference to the past. ${ }^{4}$ Thus, unlike polls issued by the Dominion Institute, the survey and associated projects did not aim to test Canadians' knowledge of the past, but their level and type of engagement with it. While many questions were borrowed from previous surveys, the team created others that asked about regional and ethnic pasts, or the 'limited identities' pertinent to the Canadian experience. The survey itself is divided into six parts that ask a range of questions about 
respondents' activities related to the past, how those activities help them understand the past, how they assess the trustworthiness of sources of historical information, which geographical regions are important to them, and how the past and the present are connected. Based on the findings of the American survey, the Canadian team broadly defined activities related to the past to encompass the more traditionally acceptable visits to museums and historic sites, and potentially more debatable activities such as playing video games and making home movies and cookbooks. $^{5}$

The results hold few surprises for those familiar with the previous surveys. In the section for activities that related to the past, looking at old photographs ranked first at $82 \%$, watching historical movies second at $77 \%$, and $74 \%$ said they were preserving heirlooms for family members or friends. Fewer respondents stated they were preparing a family scrapbook or history $(57 \%)$, sought out sites important to their own past (56\%), read historical books $(54 \%)$, or visited a historic site $(50 \%)$ or a museum $(44 \%)$ in the last year. $60 \%$ of those surveyed had participated in an average of four to eight activities. As in previous surveys, the common thread of many of the activities reported appears to be the importance of family, chosen by two thirds of respondents as the "most important" compared to religious, ethnic, regional or national stories. Even when visiting museums and other historical places, many Canadians, both new immigrants and those with roots generations old, were more likely to make connections to a broader collective or national past if there was a personal tie. When asked to elaborate on this emphasis on family, many explained it in relation to understanding their own identity. The project team calls this personal or 'usable' past "autobiographical memory." Assessing regional identities, residents of Newfoundland and Labrador were most likely to have selected their provincial past as "very important" (73\%) followed by Quebecers at 47\%. The national average was a lesser 36\%. An almost equal percentage chose the national past $(44 \%)$ and an ethnic or cultural past $(40 \%)$ as "very important." While this first finding is higher than that found in the American survey, only $8 \%$ of respondents said that Canada's past was the "most important" to them. The team has found limited identities "alive and well in Canada." Asked to rank the trustworthiness of sources of historical information, museums rated first, followed, in order, by fact-based books, family stories, school teachers, historic sites and the internet. ${ }^{6}$

Like elsewhere, school teachers will be horrified but museums will be pleased with this ranking. Museums will also be able to use the findings of the project to assist in the development of exhibits that are relevant to their communities, a must in these times of limited funding. Museums have always conducted visitor studies in order to improve their relevance, although never in such a systematic or broad-based way. Ethnographic museums will be pleased to see that First Nations are as likely as non-Native Canadians to visit exhibitions - something that could not have been said twenty, or perhaps even ten years, ago - though dis- 
appointed that they distrust the information. Since the 1992 joint task force report of the Assembly of First Nations and the Canadian Museums Association, many curators have followed its ethical proscriptions and created collaborative new exhibits to present Indigenous perspectives.

As the results of the Canadians and their Pasts survey mimicked those found elsewhere, perhaps the more interesting and useful outcomes will be the specialized side projects, many of which are ongoing. Informed by the Australian survey, the Canadian team decided to include interviews with those who communicate history to the public in museums, schools and in other ways. The Newfoundland Historical Society and the Association of Heritage Industries of Newfoundland and Labrador have begun to discuss the role of the past with heritage workers and memory-keepers in the province. The Canadian Museums Association initiated similar conversations among museum workers and volunteers, teachers and students, and members of historical societies across Canada. One of these sets of focus groups occurred in conjunction with an exhibit at the Peel Heritage Complex in Brampton entitled "Connections," which discussed how recent immigrants to the area engage in both their own historical traditions and those of Canada. Other museums targeting visitors to their exhibitions include the Musée acadien at the Université de Moncton and the Musée de la civilisation in Quebec City, which formulated questionnaires for children who toured their respective exhibits on Acadian, and Quebec and First Nations history. School age children have also participated in similar surveys administered by the Institut d'études acadiennes, and with teachers and parents at Historica Fairs. The Benchmarks of Historical Thinking project centred at the University of British Columbia (UBC) studies and promotes ways of teaching history that go beyond simple memorization of facts and events. In partnership with the Centre for Historical Consciousness at UBC, the Union of BC Indian Chiefs explored students' understanding of Aboriginal-government relations in the province, and created an online digital collection of primary sources related to land claims in $\mathrm{BC}^{7}$

For professional historians who remain unconvinced about the value of public or active history, the results of the Pasts project could increase their disdain. One problem may be that while the public does not perceive any differences between 'history' and the 'past,' professional historians in the academy and in the public history field do. The survey itself both deliberately conflated the two terms, and tested whether the public responded differently to their use. The investigators anticipated criticism of their conflation of the 'past' (what actually happened) and 'history' (how people interpret the past now), but like the American project, the Canadian team chose to use the two words interchangeably in order to avoid any negative associations respondents might have with the word 'history.' In asking their questions, the surveyors alternated the two terms but found no differences in the public responses based on which one they used. ${ }^{8}$

Academic historians will be encouraged, if surprised, that the survey 
revealed that the public understands that there are many interpretations of the past, a message that professors struggle to impart to their undergraduate students. They should also be pleased that public enthusiasm for historical pursuits is so high, but one can imagine traditional academics shuddering at the inclusion of scrapbooking or looking at old photographs as part of history; they may quite simply dismiss it as more evidence for David Lowenthal's disdainful division between 'history' and 'heritage.' The public's historical pursuits revealed in the Canadian survey share many elements of Lowenthal's 'heritage,' such as a strong interest in family, feelings of nostalgia, and the use of presentist understandings to explain the past. This criticism was levelled at the earlier American survey, and will continue to be a problem for many. ${ }^{9}$

In his book Possessed by the Past, Lowenthal recommended that history and heritage be kept separate. For those committed to public or active history, this is not possible, but it is not clear how they should utilize the information from the Canadian survey. Roy Rosenzweig and David Thelen, the two creators of the American survey did not agree on how to proceed with their findings. Rosenzweig placed the onus on professionals to better listen to and respect more the public's historical interests and understandings, while Thelen optimistically suggested that there was some common ground on which professionals and the public could come together. ${ }^{10}$ Conrad, one of the Canadian co-investigators, advises a dialogue between professional historians and the public in order to solve controversies such as the 2007 dispute over the Bomber Command interpretative panel at the Canadian War Museum. Borrowing a term from Thelen, she hopes for a participatory historical culture. ${ }^{11}$ Létourneau questions whether a return to a national narrative as the "most important" narrative is desirable. However the discipline of history develops, she believes it necessary that it be one "that creates a sense of belonging, common goals, a shareable temporality and referential diachrony, in the absence of which the present, not being anchored, will be buffeted by all identity tempests it foretells." 12 But how does one actually bridge the gap between history and heritage, the professionals and the public? Should all public or active historians start with the personal or the familial to get at larger or national stories or is this a limited approach? How can, or should, the public's use of a "mythistory," a term used elsewhere by Létourneau, be counteracted? 13 As of yet, the Canadians and their Pasts survey does not suggest how we can bridge the gap, one of their main goals, but as the results of the partner projects continue to be digested and published, hopefully models to emulate will emerge.

\section{NOTES}

1 Lon Dubinsky and Del Muise, "Partnering with the Past: The Canadians and Their Pasts Project," Muse (Jan/Feb 2008): 32; Margaret Conrad, Jocelyn 
Létourneau and David Northrup, "Canadians and their Pasts: An Exploration in Historical Consciousness," The Public Historian 31, 1 (2009): 16-17; Del Muise, "Canadians and their Pasts," Acadiensis 37, 1 (2008): 93-4. Individual and institutional partnership comes from Athabasca University; the Association of Heritage Industries, Newfoundland and Labrador; the Newfoundland Historical Society; the Musée acadien and L'institut d'études acadiennes at the Université de Moncton; Memorial University; the Musée de la civilisation in Quebec City; the Association for Canadian Studies; the Canadian Museums Association; the Historica Foundation; the Canada West Foundation; the Kamloops-Thompson Regional Historica Fair Committee; the Peel Heritage Complex; the Manitoba Museum; Parks Canada; Thompson Rivers University; and the Union of British Columbia Indian Chiefs.

2 For the US survey, see Roy Rosenzweig and David Thelen, The Presence of the Past: Popular Uses of History in American Life (New York: Columbia University Press, 1998) and http://chnm.gmu.edu/survey/. A roundtable assessing the survey was published by The Public Historian 22, 1 (2000): 13-44. In 2003, Australian Cultural History published the results of the Australian survey. The European survey is detailed in Magne Angvik and Bodo Von Borries, eds., Youth and History: A Comparative European Survey on Historical Consciousness and Political Attitudes among Adolescents (Hamburg: Körber-Stiftung, 1997).

3 For a fuller account of the survey logistics, see Conrad, Létourneau and Northrup, "Canadians and their Pasts," 24-7 and Gerald Friesen, Del Muise and David Northrup, "Variations on the Theme of Remembering: A National Survey of How Canadians Use the Past," Journal of the Canadian Historical Association 20, 1 (2009): 223-7.

4 Jocelyn Létourneau, "History in Post-Historical Times," Canadian Issues/Thémes canadiens (October 2008): 70. This was also a major finding of the US survey.

5 The full survey can be found at http://www.canadiansandtheirpasts.ca/pasts_survey.pdf.

6 Conrad, Létourneau and Northrup, "Canadians and their Pasts," 27-32;

Friesen, Muise and Northrup, "Variations on the Theme of Remembering," 230, 235.

7 See the Pasts website http://www.canadiansandtheirpasts.ca/community.html for a full list of and links to the satellite projects.

8 Conrad, Létourneau and Northrup, "Canadians and their Pasts," 20, 26n32; Friesen, Muise and Northrup, "Variations on the Theme of Remembering," 224n8; Muise, "Canadians and their Pasts," 96.

9 See, for example, Michael Kammen, "Carl Becker Redivivus: Or is Everyone Really a Historian," History and Theory: Studies in the Philosopby of History 39, 2 (2000): 233.

10 Roy Rosenzweig, "Everyone a Historian," and David Thelen, "A

Participatory Historical Culture," in Presence of the Past: Popular Uses of History in 
180

Hamilton

American Life, 177-207.

11 Margaret Conrad, "Towards a Participatory Historical Culture: Some Personal Thoughts," Canadian Issues/ Thémes canadiens (October 2008): 66-69.

12 Létourneau, "History in Post-Historical Times," 72.

13 Jocelyn Létourneau, "Remembering Our Past: An Examination of the Historical Memory of Young Québécois," in To the Past: History Education, Public Memory, and Citizenship in Canada, ed. Ruth Sandwell (Toronto: University of Toronto Press, 2006), 71.
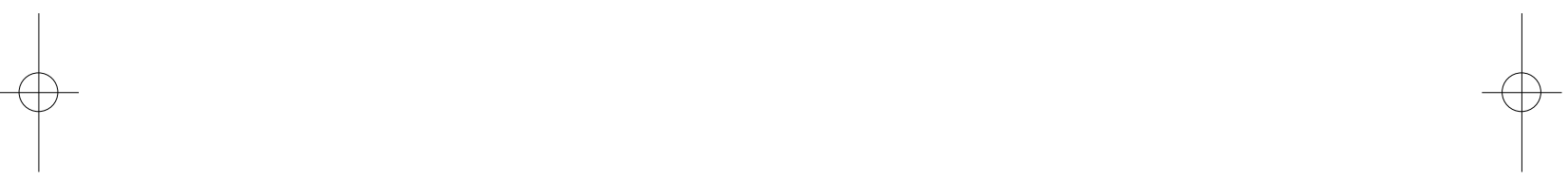